\title{
IMPACT OF FRUITS AND VEGETABLES EXPORT ON ECONOMIC GROWTH IN NIGERIA (1981-2019)
}

\author{
Okorie George Chisom ${ }^{1}$ and Nwachukwu Nnamdi ${ }^{2}$ \\ ${ }^{1}$ Department of Economics/Faculty of Social Sciences/Godfrey Okoye University, Enugu \\ State, Nigeria. Email: chisomgeo@gmail.com \\ ${ }^{2}$ Department of Economics/Faculty of Social Sciences/Godfrey Okoye University, Enugu \\ State, Nigeria. Email: nnamdinwachukwu83@gmail.com
}

Cite this article:

Okorie G.C., Nwachukwu N. (2022), Impact of Fruits and Vegetables Export on Economic Growth in Nigeria (1981-2019). African Journal of Economics and Sustainable Development 5(1), 47-58. DOI: $10.52589 / A J E S D-$ YINDFKBQ

\section{Manuscript History}

Received: 20 Jan 2022

Accepted: 5 Feb 2022

Published: 3 March 2022

Copyright $\odot 2022$ The Author(s). This is an Open Access article distributed under the terms of Creative Commons AttributionNonCommercial-NoDerivatives 4.0 International (CC BY-NC-ND 4.0), which permits anyone to share, use, reproduce and redistribute in any medium, provided the original author and source are credited.
ABSTRACT: This study empirically examined the impact of fruits and vegetables exports on economic growth in Nigeria covering the period 1981-2019. To actualize the aim of this study, data for the research were extracted from the Central Bank of Nigeria (CBN) statistical bulletin, 2019. The method used in estimating the parameters of the model was the linear regression with the application of Ordinary Least Squares (OLS) technique and the Granger causality analysis. The major findings of the study are that fruits and vegetables exports contributes negatively but insignificantly to economic growth in Nigeria, government agricultural expenditures contribute negatively but insignificantly to economic growth in Nigeria and rainfall contributes negatively but insignificantly to economic growth. It is the recommendation of this study that; the government of Nigeria should encourage farmers by giving soft loans for agricultural activities especially for fruits and vegetables. This will help farmers meet up with financial needs in terms of purchasing some seeds, hiring machines, etc thereby boosting the massive production and exportation of fruits and vegetables in Nigeria.

KEYWORDS: Fruits, Vegetables, Export, Economic Growth, Nigeria 


\section{INTRODUCTION}

Agriculture is defined as the production of food and livestock, as well as the intentional nurturing of plants and animals. As a result, agriculture is the backbone of many economies and is critical to a country's socioeconomic success. This is due to the fact that it is an important component and factor in national growth. Agriculture's importance in reforming an economy's structure cannot be overemphasized, considering that it provides food for humans and animals as well as raw materials for the industrial sector (Anayo, 2016). Horticulture is one of the many sub-disciplines of agriculture. Horticulture plays a key role and has recently emerged as one of the agricultural enterprise's potentials for speeding an economy's growth (Christian, 2019). It provides nutritional security and job opportunities, as well as great potential for sustaining a big number of agro-based enterprises that can generate a huge number of jobs for people (Peterson, 2018). Fruits, vegetables, spices, flowers, root and tuber crops, medicinal and fragrant plants, and condiments make up this category. Fruits and vegetables are among these crops that play a critical part in global horticulture production and exports.

Though Nigeria's export of fruits and vegetables fluctuated substantially in recent years, it increased through the 1970-2019 period, ending at 254,137 1000 US\$ in 2019. A brief historical trend reveals that the value of foods and vegetables output was $\$ 30,187.00$ in 2008; $\$ 31,523.00$ in 2009 ; reduced to $\$ 20,393.00$ in 2010 , which is a $-35.31 \%$ decrease from 2009 ; and increased to $\$ 33,031.00$ in 2011 . In 2012 , the value of vegetables and fruits was $\$ 462,988.00, \$ 73,471.00$ in 2013, \$125,316.00 in 2014 and $\$ 155,480.00$ in 2015 .

According to the International Trade Centre, Nigeria's edible vegetable exports are underutilized (ITC, 2015). Nigerian exports of edible vegetables, tubers, and roots accounted for only $3 \%$ of global imports, according to the ITC. India continues to be Nigeria's largest importer of edible veggies. It brought in $47.91 \%$ of the edible vegetables, tubers, and roots it needed. In 2020, the United States imported $13.17 \%$ of Nigeria's vegetables, while the United Kingdom imported $4.97 \%$. Nigeria's veggies were imported by the United Arab Emirates (UAE) at a rate of $5.91 \%$. The Netherlands received $0.09 \%$ of exports, Sri Lanka $1.31 \%$, and Turkey $1.97 \%$ (Obadan, 2021).

Despite a number of programs aimed at boosting the horticulture sub-sector, it is still relatively underdeveloped. The agricultural sub-challenges sectors are likewise reflected in the horticulture sub-sector. Inadequate production expertise and technology, insufficient planting supplies, land tenure, poor extension services, and insufficient post-harvest facilities are among these issues (Babatola, 2004).

The government's policy and fiscal restraints have limited horticultural crop development in Nigeria. In the national prospective plan for agricultural growth, it has gotten very little attention (Oseni, 2017). Furthermore, for all horticulture crops, Nigeria has only one research institute, the National Horticultural Research Institute (NIHORT), which was established in 1975. Horticultural crop production is linked to bad outcomes due to unpredictably changeable biological, meteorological, and pricing factors. Fruit and vegetable production and export fluctuate despite their importance in daily diets and the country's competitive and comparative advantage in production. For example, the average tomato output falls significantly short of the crop's potential. For example, the average production of roughly 6 tones is significantly lower than the claimed yields of 7 tones and 6.48 tones for Tanzania and Uganda respectively (Agu, 2019). Agricultural production may be sustained if resources are used efficiently. 
Furthermore, there are few studies that have been conducted to look into the impact of fruit and vegetable exports on Nigeria's economic growth. This is the driving force for this research. Based on the foregoing, the purpose of this study is to conduct an empirical analysis of the impact of fruits and vegetables on economic growth in Nigeria from 1981 to 2019.

\section{LITERATURE REVIEW}

Ebele, Ekwutosi, Christopher and Amaka (2021) used the new growth theory as a theoretical framework to study the impact of vegetable exports on Nigeria's economy from 1988 to 2018. Time series data was obtained from the World Integrated Trade Solution (WITS), the World Development Indicator (WDI), and the Statistical Bulletin of the Central Bank of Nigeria $(\mathrm{CBN})$. The study used the autoregressive distributive lag (ARDL) bounds testing technique and the error correction model. Although the coefficient for vegetable exports was negative, their findings suggest that it had a major impact on Nigeria's economic growth. Total agricultural exports, in particular, had a favorable impact on economic growth.

For the period 1988-2018, Kondal (2020) investigated whether vegetable exports led to economic growth and assessed the relationship between vegetable exports and vegetables imports, capital, and economic growth in selected SAARC economies. The empirical inferences in this work were drawn using panel econometric approaches such as LLC, IPS, Johansen-Fisher Cointegration, Fully Modified Ordinary Least Square, and heterogeneous causality. The study found that in selected SAARC economies, vegetable exports do not lead to economic growth, rejecting the export-led growth hypothesis. However, in a few SAARC economies, there is a long-term association between vegetable exports, imports, capital, and economic growth.

For the period 1981 to 2017, Talga and Ameji (2020) investigated the impact and relationship between agricultural exports and economic growth in Nigeria. Two research questions and objectives led the investigation. The study's hypotheses were tested using the Ordinary Least Square (OLS) and Johansen Co-Integration tests. The OLS regression model results demonstrate that agricultural exports have a positive and substantial association with economic growth, indicating that the agriculture sector contributes considerably to Nigeria's GDP growth.

The impact of agricultural export on Nigeria's economic growth was investigated by Mathew and Iku (2019). The long run link and influence of agricultural exports on Nigeria's economic growth were examined using the Autoregressive Distribution Lag (ARDL) econometric technique in this study. The explanatory variables are agricultural export, foreign direct investment, inflation rate, and labor force. Economic growth is the dependent variable, which is proxied by the real gross domestic product. The ARDL approach found that agricultural exports have a considerable impact on Nigeria's economic growth; this means that a $1 \%$ increase in agricultural exports will raise Nigeria's economic growth by almost $25 \%$.

Olabanji, Fakile, and Emmanuel (2017) used time series data to evaluate the long term relationship between agricultural exports and output and economic growth in Nigeria from 1981 to 2014. The results of the Johansen maximum likelihood co-integration technique and the Vector error correction model show that agricultural output and economic growth in Nigeria have a long-term link. The Granger causality test also verifies the co-integration results, demonstrating that agricultural output and economic growth in Nigeria are causally linked. 


\section{Research Design}

The investigation employed the expo-facto design. This is because the researcher had no control over the data and variables used in the investigation. This study makes use of econometric procedure in estimating the impact of public expenditures on agricultural output growth in Nigeria. It is also pertinent to note that the research design will adopt the quantitative approach based on the fact that it will give room for statistical and econometric estimations for the actualization of the research objectives.

\section{Model Specification}

In this model, fruit and vegetable exports, government agricultural expenditures, rainfall, interest rate and foreign direct investment on agriculture are the independent variables while economic growth is the dependent variable.

The model is expressed in implicit and explicit forms below:

In implicit form: RGDP $=f(F R A V, G E X P A, R N, I N R, F D I A G R)$

In explicit form: $R G D P=\beta_{O}+\beta_{1} F R A V+\beta_{2} G A E X P+\beta_{3} R N+\beta_{4} I N R+\beta_{5} F D I A G R+$ $\mu \ldots(3.2)$

where

$\mathrm{f}=$ Functional Relationship

FRAV $=$ Fruits and Vegetables Export

GAEXP $=$ Government Agricultural Expenditures

$\mathrm{RN}=$ Rainfall

INR $=$ Interest Rate

FDIAGR $=$ Foreign Direct Investment on Agriculture

$$
\begin{aligned}
& \beta^{\prime} s=\text { The Parameters of the Independent Variables to be Estimated } \\
& \mu=\text { Stochastic Error Term }
\end{aligned}
$$

\section{Pre-Estimation Tests}

\section{Unit Root Test}

This was used to see if the mean value and variance of a variable changed over time. In order to prevent the problem of false regression, it is required in time series variables. The study was conducted using the Augmented Dickey Fuller (ADF) test. When there is autocorrelation in the series and lagged terms of the dependent variable are included in the equation, the Augmented Dickey-Fuller (ADF) test is employed to see if there is a unit root. In Augmented Dickey-Fuller tests, the following three models reflect pure random walk, random walk with drift, and random walk with drift and trend: 


$$
\begin{aligned}
& \Delta \psi_{t}=\Omega \psi_{t-1}+\sum_{i=1}^{p} \beta_{i} \Delta \psi_{t-1}+\varepsilon_{t} \\
& \Delta \psi_{t}=\alpha_{0}+\Omega \psi_{t-1}+\sum_{i=1}^{p} \beta_{i} \Delta \psi_{t-i}+\varepsilon_{t} \\
& \Delta \psi_{t}=\alpha_{0}+\Omega \Psi+\beta_{2} t+\sum_{i=1}^{p} \beta_{i} \Delta \psi_{t-1}+\varepsilon_{t}
\end{aligned}
$$

where $\Omega=(\lambda-1)$. The null hypothesis is $H_{0}: \Omega=0$ and the alternative hypothesis is $\mathrm{H}_{a}: \Omega<0$

\section{Co-Integration Test}

This will be used to test if there exists a long-run relationship between the variables under investigation. The Johansen or Engel-Granger methodology will be used. The long-run equilibrium relationship is estimated with the following equation:

$$
\mathrm{X}_{t}=\alpha_{0}+\alpha_{1} \mathrm{Z}_{t}+\varepsilon_{t}
$$

If there is cointegration, $\alpha_{0}$ and $\alpha_{1}$ estimates reveal "super-consistent" estimators in the OLS regression. In this estimation fitted values of $\mathcal{E}_{t}$, the series is tested for stationarity. In this analysis, DF or ADF may be used. However, in hypothesis testing, critical values constructed by McKinnon (1991) are used. If this series is stationary, we can conclude that there is cointegration between $\mathrm{X}_{t}$ and $Z_{t}$. The fitted values of $\boldsymbol{E}_{t}$ may be used as error correction terms of the model.

\section{Error Correction Mechanism (ECM)}

If the variables under examination are discovered to be co-integrated, an econometric analysis called error correction analysis is performed. To assess the pace of adjustment of the short-run dynamics of the variables and the time of long-run convergence, the Error Correction Mechanism (ECM) was applied.

\section{Granger Causality Model}

To actualize objective two which is to estimate the granger causal relationship between fruit and vegetable exports and economic growth in Nigeria, the general granger causality model is specified thus: 


$$
\begin{aligned}
& V_{1 t}=\alpha+\sum_{j=1}^{k} \beta_{j} X V_{t-j}+\sum_{j=1}^{k} \phi_{j} X V_{t-j}+\Psi_{1 t} \\
& X V_{t}=\Omega+\sum_{j=1}^{k} \theta_{j} V_{t-j}+\sum_{j=1}^{k} \phi_{j} V_{t-j}+\Psi_{2 t}
\end{aligned}
$$

where $\mathrm{XV}$ and $\mathrm{V}$ are the endogenous variables and the lagged values are the exogenous variables.

\section{RESULTS AND ANALYSIS}

\section{Unit-Root Test Result}

Because time series data are frequently thought to be non-stationary, a unit root test is required to ensure that the data are stationary. To avoid the problem of spurious regression, the test was used. To complement each other, the Augmented Dickey-Fuller (ADF) unit root test was employed to determine the stationarity of the data. The ADF test's decision criteria is that its statistic must be bigger than the Mackinnon Critical Value at a 5\% level of significance and in absolute terms. Table 4.1 shows the results of the unit-root test.

Table 4.1: Unit Root Test Result

\begin{tabular}{|l|l|l|l|}
\hline VARIABLE & ADF STAT. & CRITICAL VAL. & ORDER \\
\hline RGDP & -1.969095 & -1.950117 & $\mathrm{I}(1)$ \\
\hline FRAV & -17.48942 & -1.950117 & $\mathrm{I}(1)$ \\
\hline GAEXP & -9.369458 & -1.950117 & $\mathrm{I}(1)$ \\
\hline RN & -7.189384 & -1.950394 & $\mathrm{I}(1)$ \\
\hline INR & -2.999236 & -1.952066 & $\mathrm{I}(1)$ \\
\hline FDIAGR & -4.674372 & -1.950117 & $\mathrm{I}(1)$ \\
\hline
\end{tabular}

Source: Author's Computation Using E-views 10.

Table 4.1 clearly shows that all the variables are stationary at first difference, I(1). This means that the variables have unit-root until differenced in the first order. This was also strengthened by the correlogram analysis. 
African Journal of Economics and Sustainable Development

ISSN: 2689-5080

Volume 5, Issue 1, 2022 (pp. 47-58)

\section{Co-Integration Analysis (Johansen Method)}

Date: 17/19/22 Time: 08:44

Sample (adjusted): 19832019

Included observations: 37 after adjustments

Trend assumption: Linear deterministic trend

Series: RGDP FRAV GAEXP RN INR FDIAGR

Lags interval (in first differences): 1 to 1

Unrestricted Cointegration Rank Test (Trace)

\begin{tabular}{ccccc}
\hline $\begin{array}{c}\text { Hypothesized } \\
\text { No. of CE(s) }\end{array}$ & Eigenvalue & $\begin{array}{c}\text { Trace } \\
\text { Statistic }\end{array}$ & $\begin{array}{c}0.05 \\
\text { Critical Value }\end{array}$ & Prob.** \\
\hline & & & & \\
\hline None ${ }^{*}$ & 0.660749 & 114.4330 & 95.75366 & 0.0014 \\
At most 1 & 0.544246 & 74.43547 & 69.81889 & 0.0204 \\
At most 2 & 0.405147 & 45.36077 & 47.85613 & 0.0842 \\
At most 3 & 0.306011 & 26.14144 & 29.79707 & 0.1245 \\
At most 4 & 0.211362 & 12.62540 & 15.49471 & 0.1293 \\
At most 5 & 0.098576 & 3.839830 & 3.841466 & 0.0500 \\
& & & & \\
\hline
\end{tabular}

Trace test indicates 2 cointegrating eqn(s) at the 0.05 level

$*$ denotes rejection of the hypothesis at the 0.05 level

** MacKinnon-Haug-Michelis (1999) p-values

Unrestricted Cointegration Rank Test (Maximum Eigenvalue)

\begin{tabular}{ccccc}
$\begin{array}{c}\text { Hypothesized } \\
\text { No. of CE(s) }\end{array}$ & Eigenvalue & $\begin{array}{c}\text { Max-Eigen } \\
\text { Statistic }\end{array}$ & $\begin{array}{c}0.05 \\
\text { Critical Value }\end{array}$ & Prob.** \\
\hline & & & & \\
None & 0.660749 & 39.99751 & 40.07757 & 0.0510 \\
At most 1 & 0.544246 & 29.07470 & 33.87687 & 0.1682 \\
At most 2 & 0.405147 & 19.21933 & 27.58434 & 0.3978 \\
At most 3 & 0.306011 & 13.51604 & 21.13162 & 0.4060 \\
At most 4 & 0.211362 & 8.785567 & 14.26460 & 0.3044 \\
At most 5 & 0.098576 & 3.839830 & 3.841466 & 0.0500
\end{tabular}

Max-eigenvalue test indicates no cointegration at the 0.05 level

$*$ denotes rejection of the hypothesis at the 0.05 level

**MacKinnon-Haug-Michelis (1999) p-values

Source: Researcher's Computation Using E-views 10 
The Johansen method of co-integration was used for the study because all the variables are stationary at first difference. The Johansen result as displayed in table 4.2 clearly shows evidence of cointegration as trace statistics test indicates at least 2 cointegrating equations as the trace statistic value is greater than that of $5 \%$ critical value $(74.43547>69.81889)$. Here we reject the null hypothesis of no co-integration meaning that there exists a long-run relationship existing between the variables (RGDP, FRAV, GAEXP, RN, INR, FDIAGR) under study.

\section{Regression Analysis (Error Correction Mechanism)}

\section{Table 4.3}

Dependent Variable: D(RGDP)

Method: Least Squares

Date: 17/19/22 Time: 08:58

Sample (adjusted): 19822019

Included observations: 38 after adjustments

\begin{tabular}{crlrr}
\hline Variable & Coefficient & Std. Error & t-Statistic & Prob. \\
& & & & \\
\hline & & & & \\
C & 0.532773 & 2.328024 & 0.228852 & 0.8205 \\
D(FRAV) & -0.109801 & 0.499144 & -0.219979 & 0.8273 \\
D(GAEXP) & -0.001924 & 0.001669 & -1.152919 & 0.2578 \\
LOG(RN) & -0.001790 & 0.017346 & -0.103169 & 0.9185 \\
D(INR) & -0.002291 & 0.006628 & -0.345603 & 0.7320 \\
D(FDIAGR) & -0.000177 & 0.000221 & -0.800669 & 0.4294 \\
$\quad$ ECM(-1) & 0.101338 & 0.163567 & 0.619553 & 0.5401 \\
& & & & \\
\hline & & & & \\
R-squared & 0.083221 & Mean dependent var & 0.015862 \\
Adjusted R-squared & -0.094220 & S.D. dependent var & 0.146866 \\
S.E. of regression & 0.153629 & Akaike info criterion & -0.743734 \\
Sum squared resid & 0.731655 & Schwarz criterion & -0.442074 \\
Log likelihood & 21.13095 & Hannan-Quinn criter. & -0.636406 \\
F-statistic & 0.469005 & Durbin-Watson stat & 0.985854 \\
Prob(F-statistic) & 0.825890 & & \\
& & & \\
\hline
\end{tabular}

Source: Researcher's Computation Using E-views 10 
It can be clearly deduced from table 4.3 that the numerical coefficient of fruits and vegetables export (FRAV) yielded a negative numerical coefficient at the magnitude of -0.109801 . This entails that fruit and vegetable exports contribute negatively to economic growth in Nigeria for the period under analysis. This does not conform to economic a priori expectations because an increase in fruits and vegetables exports should contribute positively to economic growth, but it is not the case in Nigeria.

The table also reveals that government agricultural expenditures (GAEXP) yielded a negative numerical coefficient at the magnitude of -0.001924 . This entails that government spending on the agricultural sector does not contribute positively to economic growth in Nigeria. This does not also conform to economic a priori expectation but reflects the true situation of Nigeria agricultural spending situation.

Rainfall (RN) contributes negatively to economic growth in Nigeria as the numerical coefficient yielded -0.001790 . This entails that rainfall does not contribute positively to economic growth in Nigeria. Hence, rainfall is not sufficient enough to improve economic growth and productivity.

The regression output in table 4.3 clearly shows that there is an inverse relationship between interest rate and economic growth. The numerical coefficient has a negative value at the magnitude of -0.002291 . This conforms to economic a priori expectation given the negative relationship that exists between interest rate and investment as suggested by economic theory.

Foreign direct investment on the agricultural sector yielded a negative numerical value (0.000177). This entails that foreign investment in the agricultural sector does not lead to a positive increase in economic growth in Nigeria for the period under analysis. This does not also conform to economic a priori expectations.

\section{Autocorrelation Test (Breusch-Godfrey)}

\section{Table 4.4}

Breusch-Godfrey Serial Correlation LM Test:

$\begin{array}{llll}\text { F-statistic } & 1.695410 & \text { Prob. F(2,29) } & 0.2012 \\ \text { Obs*R-squared } & 3.978015 & \text { Prob. Chi-Square(2) } & 0.1368\end{array}$

Test Equation:

Dependent Variable: RESID

Method: Least Squares

Date: 11/19/21 Time: 09:17

Sample: 19822019

Included observations: 38

Presample missing value lagged residuals set to zero. 
African Journal of Economics and Sustainable Development ISSN: 2689-5080

Volume 5, Issue 1, 2022 (pp. 47-58)

Variable Coefficient Std. Error t-Statistic Prob.

$\begin{array}{crrrr}\text { C } & -1.251523 & 2.377876 & -0.526320 & 0.6027 \\ \text { LOG(FRAV) } & 0.266523 & 0.509516 & 0.523091 & 0.6049 \\ \text { D(GAEXP) } & 0.000948 & 0.001727 & 0.549164 & 0.5871 \\ \text { LOG(RN) } & -0.003920 & 0.017153 & -0.228517 & 0.8208 \\ \text { D(INR) } & 0.000358 & 0.006595 & 0.054237 & 0.9571 \\ \text { D(FDIAGR) } & 6.74 \mathrm{E}-05 & 0.000221 & 0.304397 & 0.7630 \\ \text { ECM(-1) } & -0.123037 & 0.175019 & -0.702992 & 0.4877 \\ \text { RESID(-1) } & 0.730581 & 0.505143 & 1.446287 & 0.1588 \\ \text { RESID(-2) } & 0.567640 & 0.524567 & 1.082113 & 0.2881\end{array}$

$\begin{array}{lrlr}\text { R-squared } & 0.104685 & \text { Mean dependent var } & 2.92 \mathrm{E}-18 \\ \text { Adjusted R-squared } & -0.142299 & \text { S.D. dependent var } & 0.140622 \\ \text { S.E. of regression } & 0.150294 & \text { Akaike info criterion } & -0.749050 \\ \text { Sum squared resid } & 0.655062 & \text { Schwarz criterion } & -0.361201 \\ \text { Log likelihood } & 23.23196 & \text { Hannan-Quinn criter. } & -0.611057 \\ \text { F-statistic } & 0.423853 & \text { Durbin-Watson stat } & 1.295468 \\ \text { Prob(F-statistic) } & 0.897099 & & \end{array}$

Source: Researcher's Computation Using E-views 10.

Breusch-Godfrey (BG) serial correlation LM test was carried out to evaluate the presence of autocorrelation problem in the model. The BG output reported in table 4.5 shows that the probability of Chi-Square $\left(\mathrm{X}^{2}\right)$ yielded 0.1368 . Since 0.1368 is greater than $0.05(0.1368>$ $0.05)$, the null hypothesis of no serial correlation presence is accepted. Hence, we conclude that there is no presence of serial correlation in the model.

\section{Granger Causality Analysis}

\section{Table 4.5}

Pairwise Granger Causality Tests

Date: 11/19/21 Time: 09:21

Sample: 19812019

Lags: 2

\begin{tabular}{lccc}
\hline Null Hypothesis: & Obs & F-Statistic & Prob. \\
\hline FRAV does not Granger Cause RGDP & 37 & 0.23410 & 0.7926 \\
RGDP does not Granger Cause FRAV & & 0.38643 & 0.6826 \\
& & & \\
\hline GAEXP does not Granger Cause RGDP & 37 & 0.00971 & 0.9903 \\
RGDP does not Granger Cause GAEXP & & 9.49834 & 0.0006 \\
\hline
\end{tabular}

Source: Researcher's Computation Using E-views 10. 
It can be clearly seen that there exists a unidirectional causality relationship (causality moving from RGDP to FRAV). This entails that economic growth (RGDP) granger causes fruits and vegetables (FRAV) for the period under analysis $(0.0006<0.05)$.

\section{Hypotheses Testing}

Table 4.6

\begin{tabular}{|l|l|l|}
\hline Variable & Probability Value & Decision \\
\hline FRAV & $0.8273>0.05$ & Insignificant \\
\hline
\end{tabular}

Source: Regression Result Output

From the probability result in table 4.6, we can see that the probability value for fruits and vegetables export (FRAV) yielded $0.8273>0.05$. This entails that we accept the null hypothesis one (HO1) hypothesis one and conclude that fruit and vegetable exports have no significant impact on economic growth in Nigeria.

The granger causality result in table 4.5 clearly shows that there exists uni-directional causality between RGDP and FRAV showing causality flowing from RGDP to FRAV. This leads us to reject the second hypothesis and conclude that there is a causality relationship existing between fruits and vegetables exports and economic growth in Nigeria.

\section{CONCLUSION AND RECOMMENDATION}

From 1981 to 2019, the study was able to conduct an empirical investigation of the impact of fruits and vegetables on economic growth in Nigeria. Fruits and vegetables have a negative and small impact on economic growth in Nigeria for the period under study, according to the findings of the study. The study's conclusion is that Nigeria's agricultural economy, particularly in the horticultural sector, is yet to be built and developed. This is a result of the health sector's historically low budgetary allocation. The finding of oil is undoubtedly a setback for Nigeria's agriculture sector. In the light of the findings, the following recommendations were suggested:

1. According to the study, fruit and vegetable exports have a negative but minor impact on economic growth. As a result, the Nigerian government should promote farmers by providing low-interest loans for agricultural activities, particularly for fruits and vegetables. This will assist farmers in meeting their financial demands, such as purchasing seeds or renting machinery, hence boosting Nigeria's vast production and exportation of fruits and vegetables.

2. During the research, it was also determined that government agriculture spending has a negative but minor impact on economic growth. As a result, government agriculture expenditure must be continuously managed in order to produce the intended results in the economy. This will ensure that agriculture budget allocations are directed toward the necessary aims for economic growth. 
3. During the research, it was determined that foreign direct investment in the agriculture sector has a negative but minor impact on economic growth. The importance of attracting foreign direct investment into Nigeria's economy cannot be overstated. To achieve this increase, massive investments in power generation are required. Alternative energy sources, particularly coal resources, and solar energy should be investigated.

\section{REFERENCES}

Agu, O. (2019). The agricultural sector in Nigeria: The way forward. CBN Bullion, 21(3), 1425.

Anayo, D. M (2016). the impact of public agricultural expenditure on agricultural output in Nigeria (1981-2014). Asian Journal of Agricultural Extension, Economics \& Sociology 11(2): 1-10.

Babatola, O.O. (2004). Econometric analysis of exports and economic growth in Nigeria. Journal of Business Management and Applied Economics, 2(3), 1- 14

Christian, D. (2019). Does agriculture matter for economic development? Empirical evidence from Nigeria. Journal of Finance \& Economics, 1(1), 61-77.

Ebele, S.N., Ekwutosi, V.O., Christopher, U.K \& Amaka, M. (2021). Effect of Vegetable Exports on Nigeria's Economy. International Journal of Development and Economic Sustainability, 9(2), 23-38.

Kondal, K. (2020). The impact of federal government agricultural expenditure on agricultural output in Nigeria. Journal of Economics, 2(2), 81-88.

Mathew, C.B \& Iku, V.P (2019). The Composition of Public Expenditure and Economic Growth. Journal of Monetary. Economics, 37: 313-344.

Obada, F. J. (2021). Bounds Testing approach to Cointegration: An Examination of Foreign Direct investment, trade and Growth relationships. American Journal of Applied Sciences, 3(11):.2079-2085

Olabanji, G.O., Fakile, M.O \& Emmanuel, V. (2017). Impact of Government Sectoral Expenditure on Economic Growth in Nigeria. International. Journal.of Economiccs. Research, 3(6), $82-92$.

Oseni, A.S (2017). Agricultural resource and economic growth in Nigeria. European Scientific Journal, 8(22), 111-119.

Peterson, B.E (2019). Resuscitating agricultural production for exports. CBN Proceedings of the 10th Annual Conference of the Zonal Research Unit (pp. 109-112). Ibadan, Nigeria.

Talga, G. \& Ameji, B.N (2020). An Analysis of government spending on agricultural sector and its contribution to economic growth in Nigeria. International Journal of Business and Social Science, 2(20), 244-250. 